\title{
UDC 378.018.43:811
}

DOI: https://doi.org/10.32820/2074-8922-2020-68-80-86

\section{FOREIGN LANGUAGES DISTANCE LEARNING COURSE ORGANIZING AT A HIGHER EDUCATION INSTITUTION \\ (C) Hohol Iryna \\ Kharkiv National University of Internal Affairs}

\section{Інформація про автора:}

Hohol Iryna: ORCID 000-0001-9182-7932; irinamass911@gmail.com; PhD in Pedagogical Science, Associate Professor, Department of Foreign Languages, faculty№1, Kharkiv National University of Internal Affairs

The article attempts to characterize the foreign languages distance learning as one of the innovative training formats, effectively complementing the existing intramural and extramural education at higher education institutions. The author emphasizes that the quality and effectiveness of foreign languages distance-learning course in higher education mainly depends on how effectively it is organized; from the teachers' pedagogical skills, taking part in the training process; from the quality of methodological content, presented on the course.

This work highlights the key principles of foreign languages distance learning at higher education institutions; the means of enhancing the quality and effectiveness of education this have been determined, the main conceptual provisions of foreign languages distance learning at a university have been determined. The article proposes a model for foreign languages distance learning course organizing for future specialists, presents a system for knowledge monitoring and controlling of all types of speech activity. It is also noted that the students' independent work within the foreign languages distance course should not be passive, but on the contrary, the students should be involved in active cognitive activity; it is not limited to the foreign languages knowledge gaining, but necessarily involves their practical application; the students' independent work is used to solve certain communication problems in the future professional activities.

The conclusions of the article provide recommendations for the effective organization of foreign languages distance learning course at higher education institutions (careful selection of educational foreign language material based on the goals and objectives of the course, competent planning of the academic groups activity, regular individual and group reporting, constant consultations with a foreign language teacher) and etc. At the same time, it should be pointed out that in the process of the course organizing, in addition to the didactic characteristics and functions of multimedia and telecommunications as the technological basis of education, it is also necessary to take into account the conceptual tendencies of the didactic organization of distance learning as a component of the general modern educational system.

Key words: multimedia means, electronic information-educational environment, self-dependent work, information and communicative technologies, Internet, interactive interaction, foreign languages distance learning course, higher education institution.

Гоголь I.O. «Організація курсу дистанційного навчання іноземних мов у вищому навчальному закладі»

У статті зроблена спроба охарактеризувати дистанційне навчання іноземній мові, як один 3 новітніх форматів навчання, що ефективно доповнює заочну та очну форми навчання у вищих навчальних закладах. Авторка підкреслює, що якість та результативність дистанційного курсу 3 іноземної мови у вищій школі, головним чином, залежать від того, наскільки він ефективно організований; від педагогічної майстерності викладачів, які приймають участь у навчальному процесі; від якісного методичного змісту, що використовується на курсі.

У роботі висвітлюються ключові принципи дистанційного навчання іноземним мовам у вищих навчальних закладах; визначаються засоби підвищення якості та результативності цього формату навчання, визначаються головні концептуальні положення дистанційного навчання іноземній мові у вищому навчальному закладі. У статті запропонована модель організації курсу дистанційного навчання іноземній мові майбутніх фахівців, представлена система контролю та моніторингу знань за всіма видами мовленнєвої діяльності. Зазначається також, що самостійна робота в рамках дистанційного курсу з іноземної мови у вищій школі не повинна бути пасивною, а навпаки, студента слід залучати до активної пізнавальної діяльності, яка не обмежується придбанням іншомовних знань, а обов'язково передбачає їх практичне застосування; самостійна діяльність студентів 
використовується 3 метою вирішення певних комунікативних завдань в рамках майбутньої професійної діяльності.

У висновках статті представлені рекомендації щодо ефективної організації курсу дистанційного навчання іноземним мовам у вищих навчальних закладах (ретельний відбір навчального іншомовного матеріалу на основі цілей та завдань курсу, грамотне планування роботи академічних груп, регулярна індивідуальна та групова звітність, постійні консультації з викладачем іноземної мови) тощо. Наголошується, що у процесі організації курсу, окрім дидактичних характеристик та функцій мультимедійних засобів й телекомунікацій як технологічної основи навчання, також потрібно враховувати i концептуальні тенденції дидактичної організації дистанційного навчання як компонента загальної сучасної освітньої системи.

Ключові слова: мультимедійні засоби, електронне інформаційно-освітнє середовище, самостійна робота, інформаційно-комунікативні технології, Інтернет, інтерактивна взаємодія, дистанційне навчання іноземним мовам, вищий навчальний заклад.

Гоголь И.А. «Организация курса дистанционного обучения иностранным языкам в высшем учебном заведении»

В статье предпринята попытка охарактеризовать дистанционное обучение иностранному языку, как один из новейших форматов обучения, который эффективно дополняет заочную и очную формы обучения в высших учебных заведениях. Автор подчеркивает, что качество и результативность дистанционного курса по иностранному языку в высшей школе, главным образом, зависят от того, насколько он эффективно организован; от педагогического мастерства преподавателей, которые принимают участие в обучающем процессе; от качественного методического содержания, который представлен на курсе.

В работе освещаются ключевые принципы дистанционного обучения иностранным языкам в высших учебных заведениях; определяются средства повышения качества и результативности этого формата обучения, определяются главные концептуальные положения дистанционного обучения иностранному языку в вузе. В статье предложена модель организации курса дистанционного обучения иностранному языку будущих специалистов, представлена система контроля и мониторинга знаний по всем видам речевой деятельности. Также отмечается то, что самостоятельная работа в рамках дистанционного курса по иностранному языку в высшей школе не должна быть пассивной, а наоборот, студента следует привлекать к активной познавательной деятельности, она не ограничивается приобретением знаний по иностранному языку, а обязательно предполагает их практическое применение; самостоятельная работа студентов используется для решения определенных коммуникативных задач в рамках будущей профессиональной деятельности.

В выводах статьи представлены рекомендации по эффективной организации курса дистанционного обучения иностранным языкам в высших учебных заведениях (тщательный отбор учебного иноязычного материала на основе целей и задач курса, грамотное планирование работы академических групп, регулярная индивидуальная и групповая отчетность, постоянные консультации с преподавателем иностранного языка) и т.д. Отмечается, что в процессе организации курса, кроме дидактических характеристик и функций мультимедийных средств и телекоммуникаций как технологической основы обучения, также нужно учитывать и концептуальные тенденции дидактической организации дистанционного обучения как компонента общей современной образовательной системы.

Ключевые слова: мультимедийные средства, электронная информационно-образовательная среда, самостоятельная работа, информационно-коммуникативные технологии, Интернет, интерактивное взаимодействие, дистанционное обучение иностранным языкам, высшее учебное заведение.

Problem statement. Faced with the threat of coronavirus infection on the recommendation of the Ministry of Education and Science, Ukrainian higher education institutions have taken the decision to cross over to distance learning. In this connection, all face-to-face lectures, including lecture studies, practical classes and even laboratory sessions were moved to online environment. The teachers had to organize academic process by means of distance learning techniques based on various ways electronic content delivery and available instruments for communication of students and teachers in electronic information-educational environment. 
The abrupt switch to the distance education is forced measure; therefore, not all universities have been prepared for these developments and major restructuring of the training process based on objectively different level of information infrastructure development, availability of electronic educational resources and teachers' commitment to use digital platforms and services in the educational process.

Literature review. Distance learning has been swiftly developing and expanding around the world not just in the education system. It provides unique opportunities to obtain knew knowledge in various areas of human activity, planning time, place, learning format independently. Distance learning is a training system of highly skilled specialist, characterized by great professionalism and unfailing dedication, who is committed to working in cooperation and the required level of communication with the colleagues. Nowadays global telecommunications infrastructure provides the opportunity to create a system of continuous learning, massive and effective information exchange that do not depend on time and place of gaining the knowledge. A number of scientists and educators consider the distance learning one of the most efficient training systems and the sustained support of high professionalism of a specialist.

The purpose of the article. The issues, that directly address one of the effective training format of foreign languages teaching at the present day, namely distance learning are dealt with in the context of this article. The key principles of the given training type, ways to improve the quality and to increase the impact of the distance learning have been allocated in this work. The article attempts to define some pedagogical technologies, which should be applied in organizing a course of foreign languages distance learning at a higher education institution.

The statement of the main material. At a university, the distance learning is one of the newest formats of foreign languages teaching, successfully complementing intramural and extramural education. Attending the distance learning course, future specialists can consult with a teacher, pass tests and exams, using their personal computers in comfortable environment and time. A teacher provides educational activities in a traditional training model, but in a system of the distance learning, as a rule, the specially established structure (tutors, system administrators, administrators of the separate systems) is responsible for this activity. They provide the students by various resources of a higher education institution and manage their independent work, using educational tools, computer programs, but also a teacher retains the overall leadership role. Direct interactive collaboration between a teacher and a student is considered as a main principle of the distance learning. The methodology of foreign languages distance learning mainly aims at providing the students by understanding, comfortable classes in a traditional form, that take place virtually as Internet videoconference. Effect of face-to-face class is created through synchronous transmission of the image, mimic, sound, graphical and slide information from a teacher to a student and vice versa.

The effectiveness of any kind of foreign languages distance learning depends on the following: the successful interaction of a student and a teacher, applied pedagogical techniques in the training process, used effective methodological materials, the efficiency of feedback.

That is, the quality and efficiency of foreign languages distance learning at a higher education institution, depends mainly on effectively organized course; pedagogic mastery of teachers, taking part in the given process; qualitative methodological content, used in the training process.

Nowadays higher education institutions address the technical problem of foreign languages distance learning in different ways. Communicative and information technologies provide endless opportunities to keep, process, post and receive information of any content and quantity, irrespective of the distance. Under the circumstances, the pedagogical content of course organization forms a central part in the system of the foreign languages distance learning of students at a higher education institution, i.e. selection of educational materials as well as its structural organization and methods of foreign languages teaching.

Pedagogical techniques are well-targeted and methodical activity of a student and a teacher, which is performed to achieve the didactic objectives. The above-mentioned technologies reflect the correlation between organizational forms, methods and ways of the educational process, i.e. the organization of students' cognitive activity. Progressive pedagogical technologies, which should be applied in the organizational process of foreign languages distance course include: cooperative learning (active communication and cooperation between students and a teacher), discussions (in contrast to a simple answer, they involve free expression of students' point of view.), role and simulation games (educational games, focused on a problem, specifically related to future profession 
and allow to stage approaches to addressing the challenges through plot dramatization), situation analysis (is used as an element of simulation game or brainstorming and its aim is to teach applying gained theoretical knowledge in practice and make considered and prompt decision), project-based learning (didactic objectives are achieved through detailed development of the problem, its practical result will be concrete outcome of its activities), case technologies (focused on developing skills of self-analysis and assessment of other participants' actions). Information technologies are necessary to create, store and transfer the training materials, as well as for organizational process of distance learning by means of telecommunications technologies. Information technologies can be synchronous and asynchronous - content management system, learning management system, as well as virtual learning environment. Synchronous technologies on-line imply the simultaneous participation of the students and a teacher when learning foreign languages, for example: web- chat, ICQ, Skype, IRC (Internet Relay Chat), interactive television, teleconference Net Meeting, Telnet. Asynchronous technologies, applied off-line, do not require the simultaneous participation of the students and a teacher. A student independently chooses time and plan of foreign language lesson. Such technologies include: printed educational materials, CD-ROM, audio and video materials, e-mail, web-pages, FTP, web-forums, teleconference Usenet (subscribing to news groups).

However, a future specialist should have computer user level, as well as he/she is able to perceive authentic foreign language information on various Internet resources. This means that students should be very familiar with the following kinds of foreign language reading: reading for detail, skim reading, reading for specific information, should be capable of applying electronic dictionaries, user manuals, contained in the given course or any other server. Consequently, the foreign languages distance learning course means teaching students the above-mentioned kinds of foreign languages reading, teaching them to apply the reference electronic information.

Distinctive feature of effective distance course is its interactivity, understood as the students' interaction with the content, a teacher and other learners, according to Michael Moore (Moore, 1997, pp. 22-38) resulting in the following:

- independent design of knowledge, based on understanding and interpretation of the educational material, from own (professional) experience;
- creating the virtual educational community, which serves as a social context in which to verify new knowledge;

- multichanneling and efficiency of feedback as essential to maintaining the stable educational motivation in all forms of education;

- psychological comfort in the conditions of physical disconnection of training participants;

- improving the skills of network communication as an element of «information culture in individuals».

Content, structure and strategy for realizing distance learning course are determined by improvement of foreign languages communicative competency of students to solve the following profession-oriented tasks both orally and in writing:

- the development and speech revitalization of specialized terminology;

- improving the skills of business correspondence and learning the effective techniques for information visualization (radial schemes, mind maps, SWOT-analysis);

- the practice of dialogue and monologue speech, as a chart, forum, videoconference, essay, presentation, report, annotation of specialized authentic literature;

- improving listening skills when doing tasks after podcasts;

- strengthening skills of reasoned their own personal viewpoints at resolving problem situations (case-study technology).

Organization of the teaching process in the foreign languages distance-learning course involves three successive stages:

Organizational preparations stage familiarization with new distance course, its features, a teacher, an administrator. The distribution of trainees by groups of cooperation, based on results of primary testing, the skills development of the distance approach to the training materials, familiarization with the thematic training plan.

Basic stage - training on each module, including the learning of theoretical material; practical and control tasks for the current modules and final tests, involving the individual, group, paired tasks, considering differentiation and individualization of the learning process.

Final stage - the final evaluation of the knowledge gained in the form of the total quantity of points, according to the results of the tests in the course and the students' participation in the learning process.

Students' skills and abilities monitoring is one of the basic component of the foreign 
languages distance-learning course. There are various forms of the learners' knowledge in the process of distance learning:

- Written reports and reference papers. As a rule, they are prepared based on the results of the students' independent research work and uploaded on the course website.

- Teleconferences. They are used as the final reports for cases in which the discussion of studied topic is required. For the given kind of work, such technologies as forums can be applied in the course. The teacher is able to assess the students' knowledge as well as their skills in taking part in discussion, being able to argue and to express their views. The student can be estimated by the following criteria: activity level in a discussion (number of times a student may speak on a question), how he/she is able to ask questions on the subject and identify the central idea, etc. In addition, there may be scope for collaborative tele-projects with foreign students (international projects), organization of round tables, group and individual presentations, electronic teleconferences.

- Project methods. The teacher can evaluate the students' activities in the process of foreign languages distance learning course by means of reports, reference papers, and presentations on given subjects. Students can assess the other students (micro groups); be interviewed by a teacher (chat, forum, e-mail); participate in a discussion.

- The questionnaire is one of the most common widespread means of students' testing along with tests. The questionnaire seeks to collect detailed information, basic questions, their formulation and sequence of the wording.

- Testing. The real time tests are common methods used in the foreign languages distancelearning course. The basic forms of test tasks: multiple choice; test tasks of open type (there are no ready answers, students should formulate and write down personal answer independently on the course web-page); matching questions; arrangements in the correct succession; filling-in-the-blank in the sentences, choosing proposed words and phrases (Кравченко О.В., 2004, p. 184-190).

The tests are applied at the beginning of the course (diagnostic), in the training process (intermediate), at the end of the course (final).

The diagnostic tests are aimed to define the knowledge level, tend to learn foreign languages, interests and personal traits of students. The results of the diagnostic test are taken into consideration in the small group formation of cooperation. The intermediate tests are important to identify the students' progress or gaps in their learning activities. The given test is carried out at the end of module or some modules, as well as to monitor the certain task or under the section, paragraph. The final tests or tests for measuring learning achievement are carried out at the final stage of the learning course and provide the specific information about students' progress, their level of proficiency in foreign languages. The final test determines the graduation evaluation of the students.

The tasks for monitoring students' progress and developed foreign language skills should be varied: to complete the tasks in the limits of a practical lesson, plans, scripts and materials for carrying out of the training games, discussions, themes for the final course work etc. It is advisable to assign the tasks for students at different learning levels. In this case, a teacher of the foreign languages distance course is able to provide the students by different tasks (depending on results of previous training, speed of fulfillment, personal wishes and interests of the learners and other factors). The numbers of tasks can range, it is possible to use the crosscutting tasks related to some topics learning, and therefore to some communication sessions with online teacher. There is the single documentation in the process of the foreign languages distance-learning course including online teacher's grade book. The criteria are presented technologically in the system for online evaluating the educational attainment of students.

Organization of monitoring the knowledge gained and ways of cognitive activity should be systematic, based on timely feedback, which are already contained in the training material. The foreign languages distance learning course involves flexible combination of students' independent cognitive activity and various information sources, training materials, specially developed reference, additional background material, and ongoing operational interaction with a teacher of the distance learning course, and it does not exclude the work in the group, applying problem, research, searching methods in the work on the concrete modules of the course. In order to monitor and evaluate the efficiency of the foreign languages distance-learning course at a high school, it is possible to use specially designed web-pages, which are created by every student or group of students for themselves. The given pages significantly simplify interaction process between a student and a teacher in the distance learning.

Independent work as a part of the foreign languages distance-learning course should not 
remain inactive, and, in fact, a student should be engaged in active cognitive activity, which is not limited to the foreign language knowledge acquiring, but necessarily involves their practical application to solve concrete communicative tasks in the context of future professional activity.

The maintenance of optimal educational motivation level throughout the course takes on particular relevance working in distance learning environment with its focus on student's autonomy. In that regard, the variety of motivational resources is sufficiently broad: from actuality of multimedia authentic content, its information richness, variation and possible fast update, including the questions for discussion at the forum, proposed by the students, to the rational administrating the course, involving strict compliance with requirements of deadline, that promotes effective time planning and high pace of course dynamics.

Therefore, in organizing the foreign languages distance learning course at a higher education institution, in addition to the didactic characteristics and functions of multimedia tools and telecommunications as a technological basis of education, conceptual trends of didactic organizing distance learning as a component of a general modern educational system should be taken into consideration. Moreover, the specific character of foreign language teaching in the general should be taken into account. The above provisions are recommended for both traditional forms of education, and foreign languages distance learning course.

Conclusion and further research prospects. Therefore, the following key concepts of the foreign languages distance-learning course at a higher education institution have been defined:

- The students' practical activity should be organized, guided by the principles of interactivity, which means an experienced teacher should monitor the given activity. Education and training must be carried out in a way that enables a teacher to monitor students' activity, to correct mistakes, to monitor the progress of the training process, to manage and evaluate the students' work regularly throughout the distance-learning course.

- Effective feedback is an important element of students' independent work in the foreign languages distance-learning course. External feedback should be provided in the process of practical group activity, in communications with a teacher. Regular internal feedback process on the training material, applied in the course, should be presented. This feedback guarantees the students' self-control. Accordingly, a student can communicate with other students, supervisor of server as well as foreign language teacher in the process of distance learning course.

- Students' independent work is a base of the foreign languages distance-learning course (group work, for instance, project for two students; individual; tasks for academic group; tasks for some groups of the course, for instance, competitions, panel discussion, conferences).

For these reasons, organizing the foreign languages distance learning course, the following guidelines should be followed:

- To select training foreign language material based upon goals and objectives of the course.

- The course should include rich methodological and technological content (web pages, hypertext techniques, links to useful resources - grammatical and reference materials, specialized dictionaries etc.).

- It is essential to plan and schedule the work of the academic groups: audio and video conferencing; regular individual and group reporting should be in place; ongoing consultations with a foreign language teacher.

The programs of foreign languages distance learning courses are modelled on basic textbooks, containing the basic training information, (they may not necessarily be focused on the distance learning, but have to contain the basic information and provide substantive knowledge). We also believe, that the ways of providing educational content, proposed for the distance learning courses (including traditional printed material, video and audio materials, manuals and pedagogical tools for training courses and lessons on various topics, electronic versions of the textbooks, electronic libraries, interactive dictionaries and translators), the means of interactive engagement (opportunities offered by e-mail, voicemail, as well as electronic conferences, Internet bulletin board), the students' independent work (the principle of integrated educational environment), monitoring (testing sites and servers) can be successfully implemented in the traditional training process, complementing it, integrating into it, perfecting it.

There is extensive interest and demand for foreign languages distance learning courses all over the world, which contributes to further study and development of new forms, means and techniques of the foreign languages distance learning at a higher education institution. 


\section{Список використаних джерел.}

1. Кравченко Е. В. Внедрение компьютерных технологий в изучение иностранных языков / Е. В. Кравченко // Проблеми інженерно-педагогічної освіти : зб. наук. пр. / Укр. інж.-пед. акад. - Харків, 2004. - Вип. 6. - С. 184-190.

2. Положення про дистанційне навчання [Електронний ресурс] : Наказ М-ва освіти і науки України від 21.01.2004 p. № 40. - Режим доступу : https://zakon.rada.gov.ua/laws/show/ z0464-04\#Text - Дата звернення 25.06.2020p.

3. Теория и практика дистанционного обучения : учеб. пособие для студ. высш. пед. учеб. заведений / Е. С. Полат, М. Ю. Бухаркина, М. В. Моисеева ; под ред. Е. С. Полат. - М. : Академия, 2004. - * c.

4. Common European Framework of Reference for Languages. - Cambridge : Cambridge University Press, 2007. - 264 p.

5. Fee K. Delivering e-learning: a complete strategy for design, application and assessment / K. Fee. - London : Kogan Page, 2009.

6. Moore M. Theory of transactional distance / M. Moore // Theoretical principles of distance education / D. Keegan (Ed.). - New York : Routledge, 1997. - Pp. 22-38.

7. TESOL Teacher Education. MEdTESOL. Programme introduction. School of Education. University of Leeds. 2010 - 2011. - URL : http://www.education.leeds.ac.uk/prospective/ Дата звернення 25.06.2020p.

\section{References.}

1. Kravchenko, EV 2004, 'Vnedrenie kompjuternyh tehnologij $\mathrm{v}$ izuchenie inostrannyh jazykov'[The introduction of computer technology in the study of foreign languages], Problemy inzhenerno-pedahohichnoi osvity, Ukrainska inzhenerno-pedahohichna akademiia, Kharkiv, iss. 6, pp. 184-190.

2. Ministerstvo osvity i nauky Ukrainy 2004, Polozhennia pro dystantsiine navchannia[Provisions about distance navigation] vid 21.01.2004 roky, no. 40.

3. Polat, ES, Buharkina, MJu \& Moiseeva, MV 2004, Teorija $i$ praktika distancionnogo obuchenija,[Distance learning theory and practice] Akademija, Moskva, viewed 25 June 2020, <http://www.escc.ru/>.

4. Common European Framework of Reference for Languages 2007, Cambridge University Press, Cambridge.

5. Fee, K 2009, Delivering e-learning: a complete strategy for design, application and assessment, Kogan Page, London.

6. Moore, M 1997, 'Theory of transactional distance', in Keegan, D (ed.), Theoretical principles of distance education, Routledge, New York, pp. 22-38.

7. TESOL Teacher Education. MEdTESOL. Programme introduction. School of Education. University of Leeds 2010-2011, viewed 25 June 2020, $<$ http://www.education.leeds.ac.uk/prospective/>. 